\title{
ECOLOGICAL DYNAMICS APPROACH TO DECISION MAKING IN SPORT. TRAINING ISSUES
}

\author{
Natàlia Balagué ${ }^{1}$, Robert Hristovski ${ }^{2}$, Pablo Vazquez ${ }^{1}$ \\ INEFC University of Barcelona ${ }^{l}$, Barcelona, Spain, \\ St. Cyril and Methodius University², Skopje, Macedonia
}

\begin{abstract}
Natàlia Balagué. PhD in Biomedical Sciences, Exercise Physiology. Professor at the Department of Health and Applied Sciences, INEFC
\end{abstract} University of Barcelona. Research interests - training issues.

\begin{abstract}
The content of an athlete's perception during sports practice and the way it determines his / her decisions are some of the key questions in sport and have important consequences on the training process.

The decision making in sport (DMS), influenced by cognitivist theories, has been considered until recently as a mere mental process more or less elaborated depending on the practitioner's level. The current model, conceiving the perception of the environment and the action as separated processes, presents some limitations to explain the creativity, flexibility and adaptability that characterises the athlete behaviour.

The juxtaposition of ecological psychology and dynamic systems theory (DST) under the name of ecological dynamics offer an original and alternative perspective to understand DMS. In this way, it appears that a specific mental process to produce the decisions is no longer necessary. The decisions seem to emerge spontaneously out of the nonlinear interaction of the components of the system. The personal, task, and environmental constraints in each specific context organize those components in specific configurations that present decisions of the system. From the new perspective, the decision is fruit of the athlete's interaction with his / her context. Therefore, the athlete's function is no longer that of reacting appropriately to external stimuli, but to act upon the context to get and create information so as to act effectively.

The paper offers a brief historical outline of the evolution of the concept of DMS, explains the basis and limitations of the cognitivistic model of DMS, develops the DMS from the ecological dynamics perspective - focusing on some main concepts (self-organisation, order and control parameters and phase transitions) and some recent research results in individual and team sports - and finally presents the practical consequences of the new model in the training process at three different levels: personal, task and environmental constraints.
\end{abstract}

Keywords: decision-making in sport, ecological dynamics, dynamic systems theory, sports training.

\section{INTRODUCTION}

$\mathrm{T}$ The decision making (DM) during the sports practice is one of the most important components for performance. The DM, intimately related with the perception of the environment on the part of the athlete, is currently a topic of discussion and investigation that has important applications to sport and effective models of training. The content of an athlete's perception during sports practice and the way it determines

his / her decisions are some of the key questions at stake at present.

Until now, the cognitivist theories that have influenced the traditional models of coaching and training, consider the DMS merely as a specific mental process. As such, it appears that the athlete, after perceiving the changes of the environment, elaborates her/his actions from possible alternatives previously stored in specific 
cerebral areas. A basic aspect of this process is that the athlete should know the correct decisions or actions in advance (those related with the technique as well as those related to the sport tactics) to be able to reproduce them during the competition. With training and through the repetition of exercises the fixation of decisions is facilitated in form of representations that are the base of the athlete's response during the competition. The number of these representations allows the athlete to choose the best of the previously learnt solutions on each occasion. However, this model presents clear limitations when explaining some of the habitual situations that characterize the sport practice (e. g., how spontaneously new decisions or tactical solutions take place, how different athletes respond in a different way in front of the same situations, how different technical or tactical solutions can be learnt without previous instruction or how the flexibility and stability that characterizes the elite athlete is developed).

The DST offers an original and alternative perspective to understand the previously mentioned phenomena and to explain the DMS. To be precise, it is no longer necessary to follow a mental process to produce the decisions; they emerge spontaneously out of the nonlinear interaction of the elements of the system under influence of personal, task and environmental constraints that form each specific context (Araújo et al., 2004). Some recent studies have been able to confirm this model's applicability in sports like basketball, sailing, rugby and some combat games and sports (Hristovski, Kocarev, 2000; Araújo et al., 2006; Hristovski et al., 2006 a). The new model's adoption does not only represent a change in the form of understanding the process from a theoretical point of view but rather it claims for a change in the methods of training and in the roles developed by the athlete and the coach. The term "decision making" that is identified with the process described by the cognitivist model does not seem to be very appropriate and it can even be confusing for understanding the emergent process to which we have referred.

In this paper we intend to explain the differences among the current cognitivistic perspectives and the one based on the DST to understand the DMS and to explain the practical consequences that are derived of it. With this objective a brief historical outline of the evolution of the concept of DMS is first commented, then the current DMS based on the cognitivist model and its limitations is explained; after the DMS from the ecological dynamics perspective, focusing on the main concepts and some recent research results is presented and finally the practical consequences on the training of the introduction of the new model are reviewed.

\section{A BRIEF HISTORICAL OUTLINE OF THE CONCEPT OF DM AND DMS}

The concept of DM as an investigation topic began to take form starting from World War II, appearing like a normative theory. The conception of this theory was oriented toward finding rational optimal solutions to a decision making problem without explaining how agents select actions in natural and dynamical environments (e. g. various problems of the game theory, see for example I. M. Makarov and T. M. Vinogradskaya (1987). The main characteristic of this approach was a full known set of the alternatives and definition of the utility function to proceed in finding the mono or multi criteria optimal solutions to the decision making problems. Therefore, this model's main characteristic was centred on the "unbounded rationality" of the DM. However, this model presented some limitations:

- Humans and animals very rarely follow this process.

- The unboundedness of the rational decision - making produces problems with the computational abilities of brains and machines.

The next step given with regard to the investigation of the DM broke up with the previous concept and enlarged the role of the psychological mechanisms intervening in the process. Herbert Simon (1982) was one of the pioneers in this sense presenting in 1957 the concept of "bounded rationality". Within this concept more psychological mechanisms were introduced, about how human beings and animals chose their actions. Starting from this moment it began to be demonstrated how the DM in humans was far away from the previous normative processes. It was observed how the DMS was more closely related with principles of satisfaction, than of global optimization; that is to say, the subjects choose the most satisfactory option of those that are at hand more than among those that generally exist in his / her wider environment, but for which they are not aware. This theory 
emphasizes the fact that living organisms do not search among all possible options because they simply do not posses global information of their environment. Consequently, the decisions are not products of the rational choice among all possible alternatives or actions.

Works like those developed by G. Gigerenzer et al. (1999) centre their investigation in the concept of "bounded rationality". G. Gigerenzer's bounded rationality concept is known as "adaptive toolbox". His idea is that living organisms develop a group of simple strategies, such as search rules, stop rules and rules of decision that they hypothetically use when they decide. This second theoretical slope about the process of DM was denominated "Fast and Frugal Heuristics (FFH) (see for example G. Gigerenzer et al., 1999). The main backdrop of this concept, although much simpler and thus more powerful than its antecedents, is its lack of a unifying framework from which the heuristics will follow. Different heuristic rules such as "take the first" or "take the best" remain unconnected to some general theory which will explain them. Thus their power as engineering tools is much stronger than their power as explanatory concept.

At the moment one of the focuses that works better and have more results within the criteria of task representativeness and practical applications in sport environments is the one that tries to explain the process of DM through the ecological concept based fundamentally on the slope of the ecological psychology and the nonlinear dynamical systems theory (NDST). The juxtaposition of these two focuses, ecological psychology and NDST, is denominated as ecological dynamics and can offer an explanation about how the rules proposed by the FFH emerge and later eliminate their ad hoc character; that is to say, how the behaviour in the DM emerges without need of specific and fixed mediator processes. It claims that the necessary information to carry out the perception-action processes is already present in the environment and it is used through the interactions that take place at subject-environment scale. Therefore it is not necessary to construct a mental model or a specific representation of the environment to make decisions within this base. The interactions at an individual-environment scale reduce the need of the rationality because the decisions emerge.

\section{LIMITATIONS OF THE COGNITIVISTIC PERSPECTIVE OF DMS}

The cognitivist model of the human performance, based on the computer metaphor and the information theory, is dominant in the sports training and has a deep influence in the understanding of the processes of DMS. One of their fundamental characteristics is considering the athlete's action independently of the context (Schmidt, Lee, 1999).

According to the computer metaphor the athletes are equipped with a central processor (the brain) with important cognitive capacities in hierarchical relationship with the rest of structures and corporal functions. This processor has to be previously programmed (i. e. establish a rich set of if - then type of switches) to produce the required decisions. Hence, for a long time the paradigm of evaluating and explaining the DMS was the reaction time approach. Within this approach the athlete had to react to stimuli given by the test administrator with a fixed set of responses. The quicker his correct reaction, the higher his performance in DM was assessed. The main characteristic of this paradigm is the low degree of representativeness of this kind of tasks when compared with the situations in sport with respect to the stimuli to which athletes should respond, as well to the fixed set of alternatives from which they should choose. For example, it has been shown that these tasks have a low discriminative power when comparing experts with non-experts in sports (Hristovski, 1997).

In this sense, it is expected that the coach, who knows the sports requirements (physical as well as technical and tactical) and what the athlete should do to achieve them, is responsible for the programming. The aim of the training stimuli is to allow the athlete to be able to reproduce the requirements of each program with the highest fidelity, until the point of automation. This is achieved through explicit instructions of the exercises, through many repetitions and corrections of the deviations using athlete's internal feedback as well as the external one provided by the coach and the means of training guided to collaborate in the process (videos, etc.) (Balagué, Torrents, 2006).

From this perspective the DMS is understood as a merely specific mental process including the 
perception of the changes of the environment, the prosecution of that information and the selection of the appropriate responses among all the available motor programs previously stored in the brain during the training process.

Let us put the example of the resolution of exercises of $1 \times 1,2 \times 2$, etc. in collective sports. This type of game situations, that suppose a sub-phase of the complete game or sport, are characterized, especially in the case of the most expert athletes, for the execution of numerous varied actions that are developed at a great speed. The question would be if the process proposed by the cognitivist model - including detection and identification of the opponent's movement, association, comparison, selection and programming of the response and the execution of it - it really takes place during the game (as much in the defender as in the attacker). Another question would be how it is achieved, through those "automatisms" or movement patterns stored in our brain, to get the creativity, adaptability to the opponent and flexibility of decisions that this theory claims and that characterizes the most successful performers. In spite of what it is usually considered, these aspects are not exclusive of situation sports, since neither the conditions of the practice, the environment nor the athlete itself are repeated in any sport (e. g. sports as running, cycling or swimming).

If the DM was really the end product of the process described above, including each one of the steps that forms it, the solution would probably arrive too late to surprise the opponent. And if the athlete did not have enough flexibility and adaptability it would be very easy for the opponent to counteract. In the case of the most expert athletes the decision would be even more difficult to take due to the higher number and variety of patterns of action between which they could select, in contrast with the beginners. However, the expert athletes are able to respond more quickly, even advancing the opponent's action, and with more effectiveness than the beginners. It seems to be that instead of making globally optimal decisions (as the rational theory defends), the professionals make satisfactory decisions; that is, affordable and efficient decisions in useful time (i. e. locally optimal). This principle of satisfaction that characterizes the actions or solutions provided by the most expert athletes is partially explained, according to the classic model, for the elaboration of "automatisms" (Anderson, 1983); while the capacity of anticipation of the opponent's action finds an explanation in some more recent and sophisticated models, as the decision field theory (DFT) (Busemeyer, Diederich, 2002). The DFT explains the anticipation through the dynamics of mental representations that are developed with the practice and may anticipate the consequences of actions through a rich and complex associative process. However, the DFT is only a variant of the more classic cognitive version, in which the intermediate space of selection is a little bit more elaborated starting from the preferential responses already existent in the subject. Actually, it does not seem to represent a real change of perspective since it continues working according to an outline input-output that puts the emphasis of the decision in the individual's preferences, without considering the interaction of the decision with the context in an explicit way.

A number of DM studies in tactics is essentially descriptive and does not explain the underlying process to the DMS (Starkes et al., 2001). The verbal explanations of the athlete are studied with reference to the description of the carried out actions or the activated programs. However, what does the athlete explain: what he / she thinks that he/she has done?, what he / she thinks that he/she should have done? or what he/she would like to have done? It has been demonstrated that the brain does not consciously program (or impose) the decisions but rather the consciousness receives information about them some $300-800 \mathrm{~ms}$. after they have taken place (Libet, 1999; Haggard, Eimer 1999; Haggard, Libet, 2001). Also, most of the information on the actions does not end up being conscious, so it is that difficult, in spite of the exhaustiveness of the explanation, to understand how the process of DM can be improved.

Finally, if our actions were the result of previously stored representations, how could we explain?

- That new movements or coordinations, never practiced before or without following the previous instructions of a coach, could be generated. Let us think how children learn how to play soccer in the beaches of Brazil or how basketball players are formed in the streets of the USA. Or how we learn to walk, run, jump, speak, etc. without specific information about the correct solutions or following adult's instructions.

- The hesitating or tempting actions that precede some movements in situation sports. 


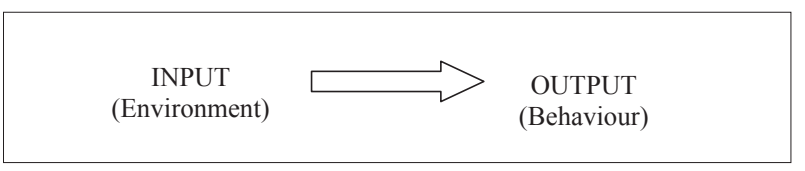

Figure 1. The cognitivist model: Environmental stimuli (input) are translated by fixed associations (i. e. switches) to the behaviour (output)

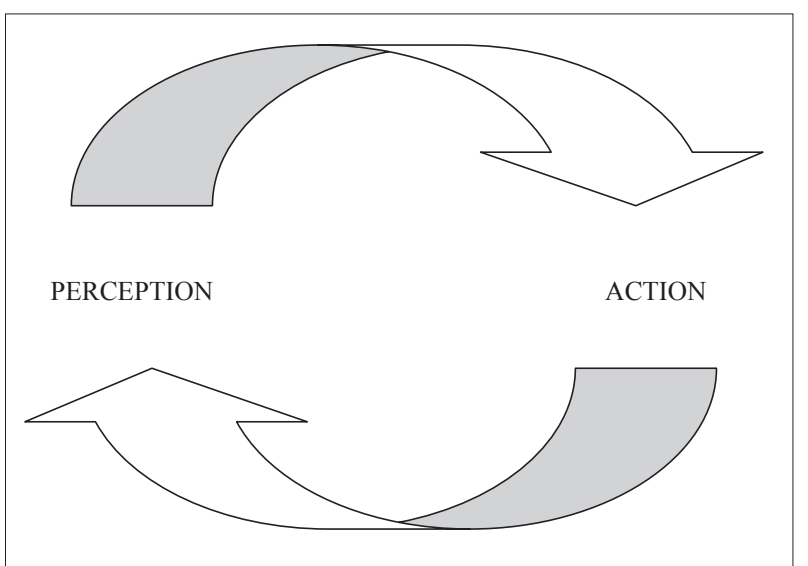

Figure 2. Circular causality of ecological psychology: Perception creates action and action creates a new perception

- That the same training information produces different results in different individuals or different results in the same individuals in different moments of the training process.

- That some athletes are able to execute certain movements under determined conditionsfor example, during the training - and that they cannot carry them out under different ones - for example, during the competition.

- That it is often not possible to carry out or to automate a movement although it is perfectly understood how it should be executed.

- That solutions considered being unorthodox for the technique or ideal tactics can produce good results.

From another point of view it is complicated to understand how our brain can store all the detailed information that comes from the environment and practice during life and to use it in each peculiar situation (this problem is most evident in the failure of the hard cognitivist concept in robotics and artificial intelligence systems).

At the moment some works (Davids et al., 2001; Araújo et al., 2006; Chow et al., 2006; Hristovski et al., 2006 a; Newell, 1986) present clear evidence that the learning processes and DM have a much more complex dynamics and claim for a more integrative approach. They are not only the result of an input-output process, where the input corresponds to the environment and the output to the behaviour, but rather they work as interactions of the individual-environment system expressed from an ecological perspective by perception-action cycles. This behaviour will be explained with more detail in the following section.

\section{THE DMS ACCORDING TO THE ECOLOGICAL DYNAMICS}

Contrary to the previous perspective and according to the DST the athletes are not conceived as programmable and externally adjustable machines by simple feedback processes but as complex non linear dynamical systems - that is to say, formed by multiple components interacting in heterarchical and dynamic non linear way (Balagué, Torrents, 2006). The basic position of the so called ecological dynamics concept is, first, that the decision making is best modelled and hence understood when treated on the performer environment level, and second, that the decisions are grounded in performer's actions. Additionally, this concept develops probabilistic characteristics of the decision-making process from deterministic laws taking into account the influence of noise present in any environment - performer system.

Within the ecological dynamics concept the "correct decisions" should no longer be programmed; satisfactory actions will emerge through self-organization processes under the pressure of interacting task, environmental and personal constraints. The self-organization is understood as a process of sudden re-organization of the system under certain conditions or internal and external constraints that press its components. For example, in the exercise of $1 \times 1$ we have referred to previously, the decisions of the attackers and defenders emerge as a result of the player's internal conditions (skill, level or fatigue, anthropometric measurements, experience, motivation...) and external (the trainer's instruction, game rules...). Especially important in this exercise are the informational constraints provided by the context that continuously guide the actions of the players (i. e. opponent's movements). In this new perspective the perception of the context is not separated from the action like in the input output model but the decisions and actions (either voluntary or involuntary) emerge under influence of certain contexts and vanish under another (for example see R. Hristovski and L. Kocarev (2000)). Also, within this framework athletes do not perceive merely the properties of the environment in objective terms as meters, seconds, aperture 
values, etc. but their scaled values with respect to the subject's bodily and action capacities. They perceive what a particular situation affords them to do - they perceive the affordances of the situation. In a similar way, the perception is a result of the action, so that the perception-action cycle repeats continually. Apparently, and in connection with the previously mentioned perception-action cycle, decisions create new actions and the latter create new sets of alternatives, which generate new decisions. Therefore, it is obvious that in dynamic environments (i. e. sport), where the time scale of change of the environmental events is similar to the time scale of decisional and action processes it is hard to reconcile the rational decision making computations on a fixed set of alternatives and successful actions of expert athletes.

Therefore, it seems that the decisions of dribbling, to dribble - pass the defender or to steal the ball are not a result of a calculating conscious mental processes which impose decisions on the action systems but emergent events arising from the relationship between the individual and the context that permanently changes during the realization of the actions. On the other hand this does not mean that the performers are not conscious of the decisions that emerge and of their consequences.

If we consider the system attacker-defender we can observe that during the exercise of $1 \times 1$ the system can present stability. That is to say, the players move but without modifying their positions regarding the objective. However, in a given moment, as a consequence of an attempt (of the attacker or of the defender), this stability can be broken and maybe the attacker surpasses the defender or the defender steals the ball. This way the game passes by stable and unstable situations that cause changes in the coordination of the system. D. Araújo et al. (2006) try to specifically understand the dynamic processes that are produced in a situation of one against one in basketball. The authors consider the existent relationship among attacker, defender and basket like a system that represents a sub-phase of the game; the attacker and the defender conform a dyad and this dyad together with the basket a complex system that can be studied with the purpose of analyzing the DM like an emergent process. The attacker's objective is to break the stability of this microsystem. While the defender is between the attacker and the basket the symmetry of the system is being maintained, but when the attacker dribbles - passes the defender, the symmetry is broken and the previous stable interpersonal state transits to a new dynamic state. As the authors point out the dyad attackerdefender becomes less stable from a critical value of the interpersonal distance. The results show how distance value (attacker-defender) decreases until arriving to a critical point where the defender or the attacker get advantage and the decision emerges, producing a reorganization of the system. In other words, while for some interval of interpersonal distances there is only one choice (stand still choice) at the critical point, for a small change of the interpersonal distance two more choices are created (dribble pass to left or right). Which ever would be carried out depends sensitively on the particular constraints of the interaction between the attacker and the defender. Hence, one observes how in dynamical contexts as the constraints (e.g. interpersonal distance) are changed intentionally by the attacker a new set of alternatives is being created. This is in a full contrast and in fact inexplicable by the cognitivist theories, which are based on the existence of a previously given fixed set of action alternatives. In the DST treatment of this problem the athlete can intentionally create sets of alternatives by changing the constraints (e.g. the context) in which she / he performs.

To describe the coordinative behaviour of the systems the DST uses the order parameters. The order parameters are collective variables that capture the dynamics of the system as a whole. This way, it is not necessary to appeal to the reductionism (to isolate variables that are studied separately) to study the behaviour. D. Araújo et al. (2006) consider the system attacker-defenderbasket as an order parameter. The position of these elements suffers changes or transitions that are characterized by rearrangement of the symmetry and they determine that one of the two players is in advantage.

As it has been pointed out previously, in certain moments of the game of $1 \times 1$, although many actions or movements of the players take place, the system or dyad remains stable. However, in a certain moment, a small change in the movement of a player can cause an abrupt change in the coordination of the system. The DST allows especially modelling this type of non linear dynamics that characterize the behaviour of living systems. During the game of $1 \times 1$ these stable states are constantly created and destroyed in accordance with the variations of the perceptive field in dynamic contexts (Davids et al., 2001). 
ENVIRONMENTAL STIMULUS

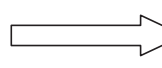

DECISION

Figure 3. Cognitivist model: The fixed set of stimuli from the environment translated by switching connections to a fixed set of possible decisions through some associative structure of mediating rules

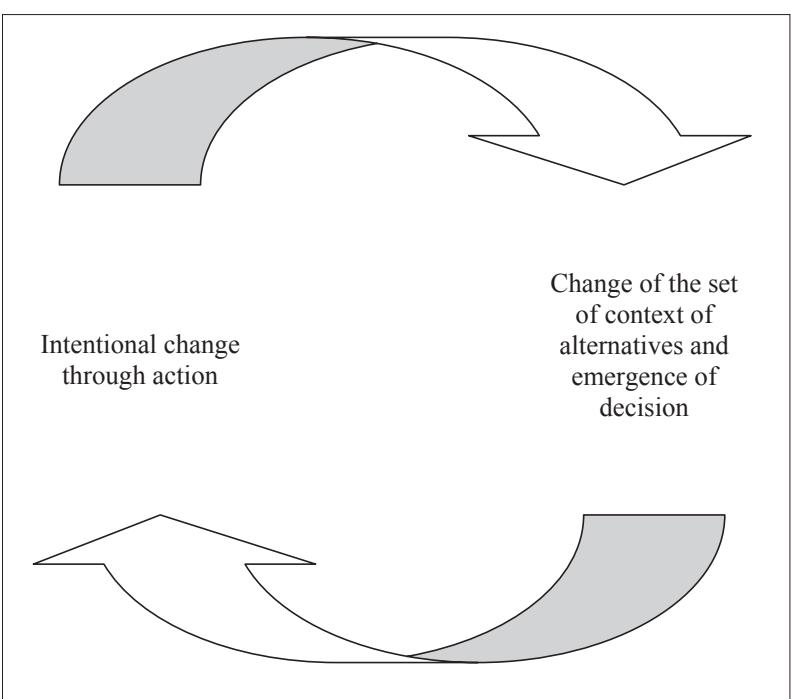

Figure 4. Ecological dynamics model of decision making: The decisions and the set of alternative actions emerge from the changes of the context generated by the performer her / himself

The DST calls attractors to these coordinative stable structures. They are point-areas of balance in the trajectory or behaviour of the systems (it is necessary to remember here that we refer indistinctly to the dyad attacker-opponent in the previous example, or in a more general way to the athlete's interaction with their context, whatever it is according to the sport). This interaction can present different attractors, depending on the description level that we study. Each of them, in spite of their characteristic stability, presents a certain grade of variability that gives the necessary flexibility to the system for the adaptive behaviour.

The combat sports also represent a good example to model these type of situations. R. Hristovski et al. (2006 a) were able to model, from the DST perspective, the actions or decisions of a boxer hitting a punch bag. The research developed by these authors seeks to show how the scaled distance to the object or opponent, conditions the type of hit selected by the boxers that is understood as an emergent process. The scaled distance is the ratio between the objective physical distance (i. e. environmental constraint) and the length of the arm that would be understood as a personal constraint.
The systematic changes of the scaled boxerobject (bag) distance, as control parameter, give origin to a cascade of changes in the number of the possible motor solutions (i. e. number of choices), producing the increase or decrease of the diversity of actions and consequently an increase or decrease of the unpredictability of decisions / actions toward the opponent. This fact is understood as bifurcations of the system, that is to say, qualitative changes and increase of complexity of its possible organizational states. The results of the investigation show that critical values exist in the scaled distances to the objective where first emergence (i. e. creation) and then a cessation of the movement pattern is produced; in other words, the decision about the type of hit emerges and is conditioned by the scaled distance (control parameter) to the opponent.

Hence, not the physical distance per se, but the scaled distance (i. e. the interaction between the environmental and personal morphological constraints) enables each individual to create her / his own actions, which form the basis of the individual solutions in different athletes in the same environmental context. Moreover, in the investigation it was shown that the perceived efficiency of strikes is dependent on the scaled distance and that this interaction between the efficiency perception and the scaled distance affordance brings about the emergence and cessation of decisions as well as their number and probability of occurrence.

Therefore, again, the number of choices (i. e set of alternatives) can be dynamically created by change of the scaled distance and the perception of strike efficiency, which is a theoretical and practical step forward when compared to the static normative or cognitivist theories of decision making. The differences between the cognitivist and ecological dynamic models are given in the figures bellow.

With this respect in ecological dynamics the change of the context through action changes the number of alternatives, their probabilities and possible decisions through dynamical mechanism of bifurcations, which in turn produces another action and change of the context, so that there exists a circular causality of actions and decisions which enhance each other, as presented in Fig. 4.

Also, this investigation showed that although for large intervals of change of the context the same solutions might be adaptive, there exist critical points where for small change of the conditions 
some tactical solutions abruptly cease to exist (they are no longer adaptive) and others more adaptive are created; which shows how robust or sensitive the decisional systems are to lengthen and minute changes of the context, respectively.

In the application to the basketball as well as in boxing, the distance and the scaled distance (interpersonal and boxer - bag, respectively) is understood as a non-specific control parameter (Hristovski et al., 2006 a) and their manipulation causes the reorganization of the system.

In summary we point out some basic concepts that characterize the DMS from the DST and ecological dynamics perspective:

- Self-organization; that is to say, the DM takes place in a spontaneous way - without any order or previous program that dictates its behaviour - as a consequence of the non linear interactions that take place between the components of the system and the environment. In this sense it is not necessary to have a pattern or program that determines the "correct" decision or action as in the previous perspective, but rather it emerges in a spontaneous way for the interaction of the "constraints" of the individual, the task and the environment that exert a pressure on the system (Torrents, Balagué, 2006). The DM is a consequence of this self-organization process.

- The presence of different organization states that are described through the order parameters or collective variables that capture the coordinative behaviour of the system. We refer to an order parameter when we speak about the relative phase between two extremities during walking or running, or the coordinated movements of the different segments during a hit in volleyball, or the angle of attack as in the boxing study.

- The control parameters are the variables that guide the system among their different organization states. They are mathematical representations of the constraints or of the context in which the system is immersed. They can be non-specific (when they have a different informative nature than the characteristic of the movement; for example, the speed or the distance among opponents) and specific (when they have the same informative nature as the movement characteristics; for example, the specific instruction of a task) (Hristovski et al., 2006 a).
- The presence of non linear changes (bifurcations or phase transitions): the changes in the control parameters do not only determine quantitative changes in the movement but rather they can cause coordinative (qualitative) changes. In some areas of the phase space a small change in the control parameter produces a non prescribed great change due to the self-organization of the system. This change comes preceded by the loss of stability of the previous organization state and it is not due to any controller agent that imposes specific solutions.

To be able to capture the qualitative changes that are produced in these systems it is necessary to have appropriate analysis tools as those that the DST offers.

Therefore, one of the most important questions to understand and to train the DMS will be to identify which are the control parameters guiding the system toward their transitions, as well as the collective variables or order parameters that suffer qualitative changes.

\section{PRACTICAL CONSEQUENCES ON TRAINING OF THE ECOLOGICAL DYNAMICAL APPROACH TO THE DMS}

The training of the DMS has been classically based on the following aspects:

- The programming of the correct decisions of the athletes - in reference to the physical condition, to the technique and to the tactics.

- A great volume of training (based on repetitions) to get an automation of the actions of the previous program.

- An analytic focus to correct the small details of the technique and tactics

- The inclusion of cognitive training. According to the model the knowledge of the technical-tactical characteristics of the sport improves the DMS. However, the capacity to verbalize or to understand how an action is carried out is not necessarily related with the capacity to execute it. In the traditional training the athletes are used to learning the correct sports techniques or tactics before beginning to practice. This aspect that can 
seemingly represent an advantage has demonstrated to present several inconveniences (Araújo, 2006):

- The athlete presents limited capacities of decision and creativity;

- The performance results are limited as a consequence of the technical emphasis;

- The qualities to participate in collective games are limited.

Indeed, the technical and tactical processes can also be learnt and trained through practice with adaptations and variants of the game. It has to be taken into consideration that the relationship between the athlete and the immediate environment suffers constant changes, what conditions in an enormous way the process of DMS (Araújo et al., 2006). The training of the DMS implies the consideration of aspects that are referred to in the personal, task and environmental constraints.

A good part of the personal constraints depends on factors that are unchangeable with the process of training. Among them we can mention: genetic characteristics (including morphological traits, physiological and biomechanical qualities, psychological traits...), previous history, previous experiences, etc). Keeping in mind that there are not two identical athletes and that they will never reproduce the same practice conditions it makes sense to limit the validity of the current prototypes determined in each sport. Numerous elite athletes are not adjusted to the established canons and often outline solutions that are not in accordance with the established models. This is not only unavoidable but it rather seems indispensable to achieve a high performance.

Regarding the task constraints, some practical consequences for the training of the DMS can be mentioned:

- The training information is no longer viewed as an external agent but as an additional constraint of the system that interact with the rest (individual and environmental constraints).

- The classic differentiations between technique and tactic actions are reduced and the same principles can be applied for their development (considering both the athlete and the team as systems).

- The exercises must maintain the functionality of the competition; that is to say, they have to keep the relationship between perception and action existing in the sport. The variations of the task can take place (distances, game rules, equipment, etc.) without breaking the essential structure of the perception-action flow. An example that would not respect this principle would be to ask to a tall basketball player with the intention that he / she gets used to jumping to catch the rebounds, to do it when its height allows $\mathrm{him} / \mathrm{her}$ to catch the ball without the necessity of jumping.

- To outline tasks in a global way (not dissociated) that contain the objective. For example, as cited by D. Araujo (2006), the exercises dedicated to master the pass in basketball can, instead of developing a means to get the basket, become an objective in itself. This way, we sometimes see during the game how the players are more pending on the circulation of the ball than on the basket options.

- To follow a process of simplification of the exercises of training instead of a process of decomposition. A classical example of decomposition can be, for instance, training separately arms and legs in volleyball, running and flight phases in jumps, or attack and defence in games. Instead of decomposing, the integration of actions facilitates the process of detection of the information and coupling the action by the practitioner. The progressive inclusion of difficulties or game rules allows developing the practice without decomposing it and keeping the perceptionaction coupling.

- To consider the functional character of the variability. The training of variable situations prepares the DM in changing situations as those that take place during the sport competition.

- To propose tasks that claim the taking of decision on the part of the athlete (e. g. situations of $4 \times 3$ in game sports).

- To identify the athlete's or team's intrinsic dynamics before outlining the objectives of the training. Start developing the practice from the natural coordinations and follow different strategies if the new tasks compete or collaborate with them (Kelso, 1999).

- Identification of the critical points through intentional varying of the contextual variables such as the scaled distance between the opponents and the distance dependent perceived efficiency of actions where the phase 
transitions in the order parameters (collective variables of the system that inform about their organization) occur. This identification through intentional change of the performance context, informs about the change of the number of alternatives, their probabilities and possible decisions (i. e. tactical solutions) and are of utmost importance for the development of the individual and group tactical behaviour. Furthermore, the identification of possible alternative actions as the context is intentionally changed brings about the exploration and identification of situations which afford the maximization of performers diversity and thus unpredictability of her / his actions which is again of immense importance for the successful adaptation in non-cooperative games like sports (Hristovski et al., 2006 a, b).

- Instead of applying big load volumes (repetitions of the same situations) cause effective instabilities to force the re-organization of the system and increase in this way the effectiveness of the training. The identification of the order and the control parameters is necessary.

- Consider that the use of implements and machines for training may alter the coupling between information and movement (e. g. the use of lance balls in tennis: the flow perception-action is altered by this artificial situation. The specificity of the training would be guided to preserve the coupling between information and movement.

- To develop tasks in a way that the variation of the constraints directs the attainment of the objectives (e. g. lift the height of the net in volleyball to get the extension of arms or the pumping of the ball) (Chow et al., 2006).

Regarding the conditions of the environmental constraints it is important to highlight the applications on the coach's role:

- The coach guides the process of training so it allows the athlete to solve in an autonomous way the varied situations that take place during the competition, instead of drifting with detail the actions that the athlete should carry out.

- To change the verbal corrections or detailed explanations about the actions for conditions of the task requiring an adaptation in the wished direction. The effectiveness of the results of the training depends in this sense on the appropriate decisions on the part of the coach.

- To identify and to manipulate the constraints provides to the athlete enough autonomy and security for DM, besides a higher motivation for the practice (Araújo, 2006).

- To direct the attention of the athlete to the external effects of the action, instead of to the corporal segments. This way there is no interference with the self-organisation process of the athlete. The coach's verbal instructions act on the intention of the athlete, making them more aware of some aspects that are considered important. The question is whether this consciousness can by itself promote changes in the decisions or if in certain situations it can create an obstacle for the coordination of the movements.

- The excessive control and the expectations can block the perception-action flow, retarding, changing or weakening the decisions of acting. For example a basketball player that fears to fail or fears the trainer's reaction shoots the ball without confidence or with an altered muscular tonus and coordination. In general the fears alter the behaviour and the effectiveness of the decision.

- In the moment of the competition the state of abandonment resembling the kid playing may favour the practice. It is necessary to forget what is learned to be able to dive in the context (Nachmanovitch, 2004).

\section{CONCLUSION}

The DM that emerges during the practice and the sport competition is one of the most important components for the effectiveness of an athlete or a team.

Until this moment the DMS has been seen as an eminently mental process and separated from the context. The perception and the action have been studied as dissociated processes, responding to a model based on the cybernetics and the theory of the information. From this perspective certain strategies have been elaborated to optimize the training of the DMS. These strategies are characterized by programming the correct responses in the athlete and attaining their automation through repetitions and corrections. Although these strategies of training are able to produce improvements in the DM and the performance of 
the athlete, they present limitations and important contradictions that make the limitations of the model evident.

The juxtaposition of the ecological psychology and the DST in the framework of the ecological dynamics propose a new perspective to understand the DMS. From this perspective the decisions are no longer a fruit of merely mental processes but rather they are emergent self-organization processes as a consequence of the individual's non linear interaction with their context. The perception and the action are viewed like an irreducible cycle. The strategies of training that are derived of the new model introduce important changes for the development of the DMS. These changes affect as much the objectives and position towards the practice and the competition, as the athlete and coach's roles in the process.

\section{REFERENCES}

Anderson, J. R. (1983). The Architecture of Complexity. Cambridge, MA: Harvard University Press.

Araújo, D., Davids, K., Bennett, S. et al. (2004). Emergence of sport skills under constraints. In A. M. Williams, N. J. Hodges (Eds.), Skill Acquisition in Sport: Research, Theory and Practice (pp. 409-433). London: Routledge, Taylor and Francis.

Araújo, D., Davids, K., Hristovski, R. (2006). The ecological dynamics of decision making in sport. Psychology of Sport and Exercise, 7 (6), 653-676.

Araújo, D. (2006). Tomada de Decisao no Desporto. Lisboa: Ed. FMH.

Balagué, N., Torrens, C. (2006). La interacción atleta-entrenador desde la perspectiva de los sistemas dinámicos complejos. Revista de Entrenamiento Deportivo, Tomo XIX, No 3, 19-24.

Busemeyer, J. R., Diederich, A. (2002). Survey of decision field theory. Mathematical Social Sciences, 43, $345-370$.

Chow, J., Davids, K., Button, C. et al. (2006). Nonlinear pedagogy: A constraint - led framework for understanding emergence of game play and movement skill. Nonlinear Dynamics, Psychology and Life Sciences, 10 (1), $71-103$.

Davids, K., Williams, M., Button, C., Court, M. (2001). An integrative modelling approach to the study of intentional movement behavior. In R. Singer, H. Housenblas, C. Janelle (Eds.), Handbook of Sport Psychology ( $2^{\text {nd }}$ ed., pp. 144-173). New York: Wiley.

Gigerenzer, G., Todd, P., the ABC Group. (1999). Simple Heuristics That Make Us Smart. New York: Oxford University Press.

Haggard, P., Eimer, M. (1999). On the relation between brain potentials and the awareness of voluntary movements. Experimental Brain Research, 126, 128-133.

Haggard, P., Libet, B. (2001). Conscious intention and brain activity. Journal of Consciousness Studies, 8 (11), $47-63$.

Hristovski, R (1997). Some Structural and Dynamical Aspects of the Visuo-motor Reaction Time in Subjects
Continually and Casually Involved in Sport Activities: Doctorial Dissertation. FFK, Skopje. P. 186.

Hristovski, R., Davids, K., Araújo, D. (2006 b). Affordance - controlled bifurcations of action patterns in martial arts. Nonlinear Dynamics, Psychology, and Life Sciences, 10 (4), 409-444.

Hristovski, R., Davids, K., Araújo, D., Button, C. (2006 a). How boxers decide to punch a target: Emergent behaviour in nonlinear dynamic movement systems. Journal of Sports Science and Medicine, CSSI, 60-73.

Hristovski, R., Kocarev, L. J. (2000). Intentional action. The Role of the Characteristic Time Scales. Consciousness Reasearch Abstracts. Toward a Science of Consciousness Conference, Tucson 2000 (p. 124).

Kelso, J. A. S. (1999). Dynamic Patterns. USA: Massachusetts Institute of Technology.

Libet, B. (1999). Do we have free will? Journal of Consciousness Studies, 6 (8-9), 47-57.

Makarov, I. M., Vinogradskaya, T. M (1987). The Theory of Choice and Decision Making. Moskow: Mir Publishers. P. 328.

Nachmanovitch, S. (2004). Free Play. Buenos Aires: Paidós.

Newell, K. M. (1986). Constraints on the development of coordination. In M. G. Wade, H. T. A. Whitting (Eds.), Motor Development in Children: Aspects of Coordination and Control (pp. 341-360). Dodrecht, Nederlands: Martinus Nijhoff.

Schmidt, R. A., Lee, T. (1999). Motor Control and Learning ( $3^{\text {rd }}$ ed.). Champaign, IL: Human Kinetics.

Simon, H. (1982). Models of Bounded Rationality: Behavioral Economics and Business Organization. London: MIT Press.

Starkes, J., Helsen, W., Jack, R. (2001). Expert Performance in Sport and Dance. In R. Singer, H. Hausenblas, C. Janelle (Eds.), Handbook of Sport Psychology $\left(2^{\text {nd }} \mathrm{ed}.\right)$ (pp. 174-201). Chichester: John Wiley.

Torrents, C., Balagué, N. (2006). DST and training methods. Ugdymas. Küno kultūra. Sportas, 1 (60), 72-82. 


\title{
EKOLOGINIS DINAMINIS SPRENDIMŲ PRIE்MIMAS SPORTO SRITYJE. TRENIRAVIMO PROBLEMOS
}

\author{
Natàlia Balagué ${ }^{1}$, Robert Hristovski ${ }^{2}$, Pablo Vazquez ${ }^{1}$ \\ INEFC Barselonos universitetas ${ }^{1}$, Barselona, Ispanija, \\ Šv. Cyril ir Methodius Universitetas ${ }^{2}$, Skopje, Makedonija
}

\begin{abstract}
SANTRAUKA
Vienas svarbiausių sporto klausimų - išsiaiškinti, kaip sportininkai per pratybas suvokia aplinką ir kaip jie priima sprendimus, nes tai labai svarbu treniravimo procese. Sprendimu priemimas sporto srityje yra grindžiamas kognityvinėmis teorijomis. Iki šiol buvo manoma, kad protinè sportininko veikla labiausiai priklauso nuo sportininko lygio. Dabartinis modelis, kurio esmè yra aplinkos ir veiksmų kaip atskirų procesų suvokimas turi trūkumų, nes jis nepaaiškina sportininko elgesio kūrybiškumo, lankstumo ir adaptyvumo.

Ekologinè prishologija ir dinaminių sistemų teorija, kurios abi vadinamos ekologine dinamika, siūlo originalų alternatyvų sporto srities modelị. Pagal šį modeli specifiniai protinès veiklos procesai, kurių metu gimsta sprendimai, nereikalingi. Atrodo, kad sprendimai gimsta spontaniškai, kaip nelinijinès sąveikos su sistemos dedamosiomis (sudètinèmis dalimis) rezultatas. Šios sistemos komponentai — tai asmeniniai, užduoties ir aplinkos trukdžai, kurie kiekviename konkrečiame kontekste sudaro specifines konfigūracijas. Tos konfigūracijos ir pateikia sistemos sprendimus. Žvelgiant iš šios naujos perspektyvos, sprendimai yra sportininko sąveikos su aplinka rezultatas. Dèl to sportininkui nebūtina reaguoti i i išorinius veiksmus, bet jis, veikdamas savo aplinkoje, turi priimti ir kurti informaciją tam, kad galètu tikslingai veikti.

Šiame straipsnyje pateikiama trumpa istorinè sprendimų prièmimo koncepcijos apžvalga, paaiškinama kognityvinio modelio esmè ir trūkumai, sprendimų prièmimas tiriamas iš ekologinès dinamikos perspektyvos, remiantis pagrindinėmis jos sąvokomis (saviorganizacija, tvarkos ir kontrolès rodikliais, pareiga) ir naujausių individualaus ir komandinio sporto tyrimų rezultatais. Galiausiai šia apžvalga pateikiame ir praktinę naujojo modelio reikšmę treniravimo procesui trimis lygiais: asmeniniu, užduoties ir aplinkos.
\end{abstract}

Raktažodžiai: sprendimų priėmimas sporto srityje, ekologinè dinamika, dinaminių sistemų teorija, sporto treniruotè.

Gauta 2008 m. rugsèjo 24 d.

Received on September 24, 2008

Natàlia Balagué

Accepted on December 9, 2008

INEFC Univ. Barcelona

(INEFC universitetas, Barselona)

Avda. de l'Estadi s/n

08038 BARCELONA

Spain (Ispanija)

Tel +34 934255445 (243)

Fax +3493 4263617

E-mail Natalia.Balague@inefc.net 